\title{
A Spatial Philosophical Interpretation of the Concept of Coordinated Development
}

\author{
Pengfei Liu \\ School of Marxism Studies, Dalian University of Technology, Dalian, 116000, China
}

Keywords: harmonious development concept; space philosophy; spatial justice; Neo-Marxism

\begin{abstract}
The coordinated development concept and the spatial philosophy theory reaches the same goal or conclusion from different approaches. The spatial philosophy research of coordinated development concept should have righteousness as Marxism spatial justice concept in China practices. This paper tries to integrate coordinated development concept into space philosophical paradigm within the study, for a step-by-step development philosophy of excavation coordination in space under the viewing angle of the philosophy of applicable experience, with both theoretical and practice value.
\end{abstract}

\section{Introduction}

The coordinated development concept core content is the analysis, the research, corrects in the Chinese urbanization advancement the space resource distribution unbalanced, the geography space development unbalanced, the information space dissemination unbalanced, the policy space coordinated unbalanced and so on the questions, the key emphasis is city and countryside region coordinated development, economic society coordinated development, promotion new industrialization, informationization, urbanization, agriculture modernization synchronization development. It pursues is in the space developing process concept justice, the system justice and the practice justice.

\section{The Value Orientation of Spatial Justice in Coordinated Development Concept}

How to reasonably appropriate spatial justice apriority and empirical against the second law (antinomies), is a profound philosophical question, this coordinated development concept is to pay attention to and solve the basic problem. Coordinated development is a kind of trying to shift the space production process the development of china-africa justice values, under the guidance of justice thought, in the space we can commence on the coordinated development of the philosophical thinking of the three aspects: the first is how to solve the natural science and social productivity today which progresses by leaps and bounds, people demand for the explosive growth of the space use and the ability to manage the contradiction between the spatial distribution of wisdom. The second is for social philosophy thinking space, namely the existing social space rules formulated and criticism. The third is on the analysis of the subjective social psychology and human spirit, in the space of human experience in the process of psychological and feelings of care and maintenance. Today we focus on the space actually is a kind of global capital flows and the reality of the power operation field or under the action of capital and power production of urban space, regional space, the reality of the global space production places. All human activities within the reality location should conform to a space already the theoretical paradigm of philosophy, more should seek a realistic guiding significance to the possibility of general universal theory and practice.

\section{The Mind Practice of Spatial Justice of Marxism Philosophy in Coordinated Development Concept}

Marx and Engels discussed about space problem generally can be divided into three stages, in which we briefly overview. The first stage. In the $1840 \mathrm{~s}$ was a period of form of city space by Marx 
and Engels thoughts, young Marx said in the article "Rhine newspaper requirements, formulate rules for township of equality of urban and rural areas, and in the lead article made it clear that equality is the" urban area and rural township of equal rights ".It was his for the early thinking to solve the problem of equality between urban and rural areas, this kind of thinking has shown young Marx concerns for urban space. Engels, meanwhile, also in German and French yearbook and contradictory the city space in the journal of vorwarts develop critical discourse. "The big tenancy competition and the land-holding peasant pushes aside the young tenancy from the market, causes them to be disappointed destitutely; Therefore, they turn muttered and depends on the wages life the weaver, these people flow in the city in large numbers, makes the city to expand by the extremely astonishing speed." This is Engels for British urban and rural problems, which contains the prominent contradiction between industry and agriculture, urban and rural criticism, represents the Engels early formation of the urban space theory. Second, perfect stage. This stage Marx Engels started their cooperation and coursed in its work the city questions a more thorough ponder. Marks the birth of historical materialism "the German ideology," says: "a nation's internal division of labor, the first cause the separation of industry and commerce with the agricultural labor, thus causing the separation of urban and rural areas and urban and rural interests. The further development of the division lead to the separation of commercial and industrial labor. At the same time, because these different department internal division of labor, between individual who is engaged in some kinds of work together forms the different division of labor. This kind of division of labor reciprocity is decided by the agriculture labor, the industry work and the commercial work management way (patriarchy, slavery, rank, social class).Under the contact quite developed condition, the similar situation also can appear reciprocity in various nationalities' between.” Marx and Engels think that the change of production relation lead to the division of Labour, and the division of labor and private ownership is a major cause of class differentiation, urban and rural contradictions occur. "The Communist Manifesto" and "Communist party Principle" from a deeper level to the private ownership production, the development and the elimination has made the elaboration. For instance: "The social all member composes the common unified body comes to have the plan to make the best together the productive forces; Develops the productive forces can satisfy the scale which all member needs; The elimination sacrifices some person's benefit to satisfy another some person's need situation; Thorough elimination social class and social class opposition; Through eliminates the old division of labor, carries on welfare which the production education, the transformation kind of work in a factory, enjoy everybody to create together, as well as the city and countryside fusion, the social all member can obtain the comprehensive development; - - This is abolishes the private ownership main result”. During this period, Marx and Engels's urban spatial justice thought gradually formed, the critical eyes shifted ownership form of capitalism, capitalist mode of production and capital accumulation. Third, the complete phase. The birth of das kapital marked the beginning of this stage, Marx in the capital by research and development of the capitalist productive forces the capitalist mode of production analysis reveals the capitalist problem at the root of the urbanization, and then puts forward the path. Same time, Engels in "Discussed Housing problem", "Anti-Duhring" through with Du Lin, Proudhon and mil Borger et al. in the controversies has consummated it about the city question elaboration. Marx and Engels during this peri will be a critique of capitalist urban space problem to criticism of the capitalist mode of production.

Coordinated development concept statement has certain time background, after first it is unifies the reform and open policy near 40 years the Chinese space production actual situation to propose. In this stage, we have obtained the result in certain domains which attracts worldwide attention, but the partial high speed development modus is not the current Chinese space production complete landscape. Because the development speed excessively quickly, the development was insufficiently experienced causes China to leave behind in many aspects or was having the very many spatial development unbalanced problems. If focuses from the question place, this the space problem which with same year Marx, Engels criticized has certain common traits and the model. 


\section{The Empirical Philosophy of Spatial Justice in Coordinated Development Concept}

Based on the classical marxist theory of space, we can undertake empirical philosophy of coordinated development concept extension and application. Classical marxism thinks that only the government can make up the defects of capital circulation. How does the government shoulder to the coordinated development guidance heavy responsibility, sets up one kind of correct value concept, guides the people to enter one kind regarding to solve the Chinese space development problem to the material pursue way harmonious condition to be extremely important, also is the important topic which the spatial philosophy needs to study thoroughly. Coordinating development concept as the "Thirteen-Five" program of social development established by the Communist Party of China, fully aware of policy innovations produced an important role in guiding and regulating capital space, this is a classic Marxist concept of spatial justice experiential philosophy applies. It also puts forward higher requirements to local government, the development of Chinese local government in formulating relevant planning, distribution pattern was more to do with the person this, balanced and must not be simply controlled by the capital logic to sacrifice human justice as a means to boost GDP index, cannot make city space capital more space, planning of the urban planning into capital.

\section{Conclusion}

In the final analysis, or "coordination" problems unsolved, we should pay attention to the space in the urban and rural integration work of equality, humanism and the assurance of diversity, achieve the complementary advantages between the urban and rural areas, the benign interaction, thereby eliminating barriers between urban and rural areas, the residents and the villagers organic union, the income level, living conditions and values can reach the balance of a human justice. Moreover, in housing space stratification plane. Since long ago, the housing space turned the very many benefit main body in under the capital logic control to carry on the capital by the favorable spatial product, they have entrusted with the exchange value which if the use value was very different. This is typical for deviating from the urban spatial justice. The solution housing space problem must take the coordinated development concept as the instruction, on the one hand initiative green plan, humanities plan, safeguard plan, on the other hand also must set up one kind of just housing concept, initiates the people to form one kind of correct housing values, abandons the capital logic in the housing process, choice pragmatism, the attention coordinates the sustainable development.

\section{References}

[1] "Marx Engels Anthology" 1st volume, Beijing: People's Publishing Agency, in 1995 version, 312th page.

[2] "Marx Engels Anthology" 1st volume, Beijing: People's Publishing Agency, in 2009 version, 96th page.

[3] "Marx Engels Anthology" 1st volume, Beijing: People's Publishing Agency, in 2012 version, 147th page.

[4] "Marx Engels Anthology" 1st volume, Beijing: People's Publishing Agency, in 2012 version, 308th page. 